\title{
COMPETENCE APPROACHES: REVIEW OF CURRENT CONCEPTS AND THEORIES
}

\section{${ }^{\text {a} L U K A ́ S ̌ ~ V R A N I A K, ~ ' L U K A ́ S ̌ ~ M A Z A ́ N E K, ~}$ 'ZDEŇKA KONEČNÁ}

Brno University of Technology, Faculty of Business and Management, Department of Management, Kolejní 2906/4, 61200 Brno, Czech Republic

email: ${ }^{a}$ lukas.vraniak@vutbr.cz, ${ }^{b}$ mazanek@fbm.vutbr.cz,

ckonecna@fbm.vutbr.cz

Project: Identification of leadership competencies which support their successful work in the international environment. Reg. No. FP-J-17-4284.

Abstract: Purpose of the article: Purpose of the article is to provide an overview of the original ideas and theoretical approaches in the field of competence approach of project managers. Methodology/methods: A comprehensive review of the most cited scientific literature and articles published predominately in past ten years in personnel oriented journals was carried out. Scientific aim: The contribution is the identification of the different understanding of competence and competency definitions and competence based approaches (Management by Competencies, Competence models) to obtain holistic view and the ability to perceive competences/competencies as an important part of project management in all its contexts. Findings: There had been identified differences in perception of competence and competency. Next up competencies were classified and application of competency model in work of project competencies were classified and application of competency model in work of project managers thanks to management by competencies had been introduced. Conclusions: The paper provides better understanding of the topic and are subsequently a basis for companies with project passed organizational structure.

Keywords: competence, competency, management by competencies, model of competencies, project management, competency models

\section{Introduction}

Drawing on the theoretical insights from the resource-based view of strategic management, Lado and Wilson, 1994 in their article explored the potential of human resource systems to facilitate or inhibit the development and utilization of organizational competencies. (Lado and Wilson, 1994). Human capital competencies, understood as those talents, skills and capabilities that contribute to multi-factor productivity gains, are perceived as a key element for sustainable economic growth and development in the globalize economy (García-Aracil and Velden, 2008).

The identification of a competency profile for superior project managers could therefore form an important step in the development of improved HRM approaches in the industry, especially given the key importance in managing people at the operational level (Cheng et al., 2005). Successful organizations rely on their employees acquiring a range of core competencies (Brophy and Kiely, 2002).

Since the recognition of projects as the major business endeavors for executing new business opportunities in a rapid changing market environments (Brady and Davies, 2004 and Söderlund and Tell, 2011), the evolution of project management in theory and practice has placed the project manager and his/her competencies at the center of a project's, and an organization's, success (Loufrani-Fedida and Missonier, 2015). From the incessant project failures, project delay and cost overrun to extreme difficulty in agreeing on what constitute project success and project management success, project management practice is more challenging in the 21st century than previously propounded (Alotaibi and Mafimisebi, 2016). Faced with this problem, both the demand for project managers and the interest in project management competencies have increased (Bredillet et al., 2015).

\section{Competency vs. competence}

There is no one broadly accepted approach toward the terms of competency and competence in the reviewed publications and each author define these two expressions with their own definitions.

Even many people consider the competency and competence as the same, the researchers differ these two words with different explanations, argue that competence and competency models have been used in three different areas: recruitment, skill assessment and development (Rowe, 1995). Definitions' overview of 6 most cited authors is shown in following table.

Table 1. Competency/competence definitions

\begin{tabular}{|c|c|c|}
\hline $\begin{array}{l}\text { Author/s } \\
\text { (publ. year) }\end{array}$ & Competence & Competency \\
\hline $\begin{array}{l}\text { Woodruffe } \\
\text { (1993) }\end{array}$ & $\begin{array}{l}\text { Is what a person brings to } \\
\text { the job }\end{array}$ & $\begin{array}{l}\text { Is a set of behavior } \\
\text { patterns that the } \\
\text { incumbent needs to } \\
\text { bring to a position to } \\
\text { perform its tasks } \\
\text { and functions with } \\
\text { competence }\end{array}$ \\
\hline $\begin{array}{l}\text { McConnell } \\
\text { (2001) }\end{array}$ & $\begin{array}{l}\text { Individual's capacity to } \\
\text { perform job } \\
\text { responsibilities. }\end{array}$ & $\begin{array}{l}\text { Focuses on an } \\
\text { individual's actual } \\
\text { performance in a } \\
\text { particular situation. }\end{array}$ \\
\hline $\begin{array}{l}\text { Teodorescu } \\
\text { (2006) }\end{array}$ & $\begin{array}{l}\text { The state or quality of } \\
\text { being adequately or well } \\
\text { qualified; ability. A } \\
\text { specific range of skill, } \\
\text { knowledge, or ability }\end{array}$ & $\begin{array}{l}\text { The quality of being } \\
\text { adequately or well } \\
\text { qualified physically } \\
\text { and intellectually }\end{array}$ \\
\hline $\begin{array}{l}\text { Hroník et al., } \\
\text { (2008) }\end{array}$ & $\begin{array}{l}\text { Expertise - knowledge } \\
\text { and skills necessary for } \\
\text { the performance of } \\
\text { eligible roles, which are } \\
\text { also referred to as a hard } \\
\text { skill. They may be } \\
\text { referred to as the } \\
\text { minimum qualification } \\
\text { requirements and are } \\
\text { derived from a specific } \\
\text { post. }\end{array}$ & $\begin{array}{l}\text { Soft skills that are } \\
\text { necessary for } \\
\text { successful job } \\
\text { performance. It is } \\
\text { the ability to behave } \\
\text { in a manner that } \\
\text { results in achieving } \\
\text { the objectives. }\end{array}$ \\
\hline $\begin{array}{l}\text { Khan and } \\
\text { Ramachandran } \\
\text { (2010) }\end{array}$ & $\begin{array}{l}\text { It could be the ability to } \\
\text { make satisfactory and } \\
\text { effective decisions or to } \\
\text { perform a skill in a } \\
\text { specific setting or } \\
\text { situation. It includes } \\
\text { metacognition, because } \\
\text { competent individuals are } \\
\text { assumed to reflect upon } \\
\text { their knowledge, skills } \\
\text { and functioning }\end{array}$ & $\begin{array}{l}\text { The habitual and } \\
\text { judicious use of } \\
\text { communication, } \\
\text { knowledge, } \\
\text { technical skills, } \\
\text { clinical reasoning, } \\
\text { emotions, values, } \\
\text { and reflection in } \\
\text { daily practice for the } \\
\text { benefit of the } \\
\text { individual and } \\
\text { community being } \\
\text { served }\end{array}$ \\
\hline $\begin{array}{l}\text { Leung et al. } \\
\text { (2016) }\end{array}$ & $\begin{array}{l}\text { Competence is a } \\
\text { combination of the } \\
\text { complex attributes of } \\
\text { knowledge, skills, and } \\
\text { attitudes; with the ability } \\
\text { to make professional } \\
\text { judgement and to perform } \\
\text { intelligently in specific } \\
\text { situations. }\end{array}$ & $\begin{array}{l}\text { Is described as an } \\
\text { underlying } \\
\text { characteristic of } \\
\text { performance; it is } \\
\text { multifaceted and } \\
\text { difficult to measure }\end{array}$ \\
\hline
\end{tabular}

Source: self-processed, 2017.

To compare the meanings authors in their definitions perceive the competency as mostly knowledge, skills, mindsets, thought patterns, and the like used whether singularly or in various combinations, result in successful performance and on the other side the competence is a function of worthy performance, which is a function of the ratio of valuable accomplishments to costly behavior. (Teodorescu, 2006) Broadly speaking, competence reflects a person's cognitive approach to a task, encompassing the multiple attributes of knowledge, skills and attitudes whereas competency highlights a person's ability to perform those tasks within the defined context of professional practice (Leung et al., 2016)

Moreover Raines (2010) argues that competencies are characteristics that drive performance in a given job, role, or function with self-reflection is an integral process to recognizing and assuring competency (Raines, 2010). Maintaining and improving competence and competency is challenging, their retention depends to a great extent on continued use and familiarity with the subject matter - moreover, research reveals a 
distinction between the retention of knowledge and skills (McConnell, 2001).

\section{Classification of competencies}

There exist some differences in perspective on how competencies should be categorized. Sparrow and Hiltrop (1994) suggest that competencies fall into three categories: behavioral, managerial, and core. Heijke et al. (2002) distinguish three groups of competencies: those acquired in school, which are of direct use in later work; those acquired in school, which facilitate acquisition of new competencies after graduation from school; and those acquired mainly in a working context. A well-known classification of competencies is Becker's distinction between general and firm-specific competencies, which Nordhaug (1993) refined and extended by distinguishing between competencies specific to firms (firm-specificity), tasks (task-specificity), and economic sectors (industry-specificity)(García-Aracil and Velden, 2008).

Kuijpers (2000) adopts an even broader perspective and proposes a typology of competencies which consists of three levels:

1. General working competencies, which she defines as competencies required for different working situations and at different time periods.

2. Learning competencies, which consist of a bundle of competencies which facilitate the development of working competencies.

3. Career related competencies, which are defined to manage working and learning competencies within a personal career path.

Various dimensions of the measurement debate are articulated in the literature: specifically, the lack of a universal model of competence and a universal understanding of the phenomena of competence. Many contributions have sought to present classifications or typologies of competency, moreover specific measurement and classification issues emerge (García-Aracil and Velden, 2008)

\section{Competency models}

In today's competitive and constantly changing business environment, competency models may be able to help professionals improve the skills set and efficiency level of their workforce to match changing market trends, in order to face competitive business challenges (Gangani et al., 2008). A competency model refers to a group of competencies required in a particular job (according Bozkrut (2011) it is usually 7-9 competencies) depending upon the nature and complexity of work along with the culture and values of the organization in which the work takes place, which can be developing for specific jobs, job groups, organizations, occupations or industries (Bozkurt, 2011). The competency model is useful to identify capabilities and attributes needed to meet current and future staffing needs of managers, and to its development efforts to eliminate the gap between capabilities needed and those available, moreover it would enable managers to perform more effectively, and lead to develop the dimensions of effective management and leadership behavior (Wu and Lee, 2007). Hogan and Kaiser (2005) we review the concept of competency-the usual outcome of the learning process-and show how all competency models can be organized in terms of a hierarchical domain model:

Table 2: The Domain Model of Competencies

\begin{tabular}{|l|l|}
\hline Domain & Definition of competencies \\
\hline Intrapersonal & $\begin{array}{l}\text { Internalized standards of performance; able } \\
\text { to control emotions and behavior (courage } \\
\text { and willingness to take a stand; career } \\
\text { ambition and perseverance; integrity, } \\
\text { ethics, and values; core self-esteem and } \\
\text { emotional stability; patience; tolerance of } \\
\text { ambiguity) }\end{array}$ \\
\hline
\end{tabular}

\begin{tabular}{|l|l|}
\hline \multirow{5}{*}{ Interpersonal } & $\begin{array}{l}\text { Social skill role-taking and role-playing } \\
\text { ability; talent for building and maintaining } \\
\text { relationships (political savoir faire, peer } \\
\text { and boss relations, self-presentation and } \\
\text { impression management, listening and } \\
\text { negotiating, oral and written } \\
\text { communications, customer focus, } \\
\text { approachability) }\end{array}$ \\
\hline \multirow{5}{*}{ Business } & $\begin{array}{l}\text { Abilities and technical knowledge needed } \\
\text { to plan, budget, coordinate, and monitor } \\
\text { organizational activity (business acumen, } \\
\text { quality decision making, intellectual } \\
\text { horsepower, functional/technical skills, } \\
\text { organizing ability, priority setting, } \\
\text { developing effective business strategy) }\end{array}$ \\
\hline $\begin{array}{l}\text { Influence and team-building skills } \\
\text { (providing direction, support, and standards } \\
\text { for accomplishment; communicating a } \\
\text { compelling vision; caring about, } \\
\text { developing, and challenging direct reports; } \\
\text { hiring and staffing strategically; motivating } \\
\text { others; building effective teams; managing } \\
\text { diversity) }\end{array}$ \\
\hline Leadership
\end{tabular}

Source: Hogan and Warrenfeltz (2003)

In brief, this model identifies four broad classes of managerial competencies with 3 main properties: developmental (Intrapersonal skills develop first leadership skills as last); hierarchy of increasing trainability (intrapersonal skills are hard to train and leadership skills easiest to train); model is comprehensive (every existing competency model can be organized in terms of these four domains) (Hogan and Kaiser, 2005).

\section{Competencies of project managers}

Project management is a complex process targeting multiple outcomes and project management competency is just as complex, requiring the acquisition of a variety of knowledge and skill sets that often cross areas of expertise, including instructional technology, management, information technology, engineering, and manufacturing (Brill et al., 2006). Project from the definition has specific objective to be completed within certain specification; has a start and end dates; has funding limits; consume human and nonhuman resources and it is multifunctional process, what defines the project management as 5 process groups within the project: initiation, planning, execution, monitoring and control, closure. Brill at al. (2006) identified 10 top competencies with influence on the project success:

Table 3: Top 10 competencies of project manager needed

\begin{tabular}{|c|c|c|}
\hline Rank & Category & Competence \\
\hline 1 & $\begin{array}{l}\text { Context } \\
\text { Knowledge }\end{array}$ & $\begin{array}{l}\text { know the goals of the } \\
\text { project }\end{array}$ \\
\hline 2 & $\begin{array}{l}\text { Context } \\
\text { Knowledge }\end{array}$ & know the scope of project \\
\hline 3 & $\begin{array}{l}\text { Problem-solving } \\
\text { Expertise }\end{array}$ & conduct business ethically \\
\hline 4 & $\begin{array}{l}\text { Context } \\
\text { Knowledge }\end{array}$ & $\begin{array}{l}\text { know the mission of the } \\
\text { project }\end{array}$ \\
\hline 5 & $\begin{array}{l}\text { Context } \\
\text { Knowledge }\end{array}$ & $\begin{array}{l}\text { know how project success is } \\
\text { measured }\end{array}$ \\
\hline 6 & $\begin{array}{l}\text { Communication } \\
\text { Expertise }\end{array}$ & listen effectively \\
\hline 7 & $\begin{array}{l}\text { Leadership } \\
\text { Expertise }\end{array}$ & share credit for successes \\
\hline 8 & $\begin{array}{l}\text { Context } \\
\text { Knowledge }\end{array}$ & $\begin{array}{l}\begin{array}{l}\text { know the available } \\
\text { (funds, } \\
\text { resources } \\
\text { equipment, people, and the } \\
\text { like) }\end{array}\end{array}$ \\
\hline 9 & $\begin{array}{l}\text { Communication } \\
\text { Expertise }\end{array}$ & $\begin{array}{l}\text { have strong verbal } \\
\text { communication skills }\end{array}$ \\
\hline 10 & $\begin{array}{l}\text { Problem-solving } \\
\text { Expertise }\end{array}$ & $\begin{array}{l}\text { be able to recognize a } \\
\text { problem }\end{array}$ \\
\hline
\end{tabular}

Source: (Brill et al., 2006) 
From previous cases of project failures can serve as useful tool to avoid mistakes in managing present projects (Kerzner, 2013). Usually all failures can be used as lessons learned for the future projects and improve the success factor, but Alotaibi and Mafimisebi (2016) argues that is also important to acknowledge that not all cases of project failures may be useful to project managers in practice because of the unique characteristics of project.

\section{Management by competencies}

The systems of competency management are based on the various models and approaches in different countries (Aubret et al. 2005). Plamínek and Fišer (2005) claim that there is a connection between all the successes and failures of an organization and competencies of its employees. For this reason, all problems can be resolved through competencies (so-called competency rule) and then we can say that management of organizations that is based on competencies (Lišková and Tomšík, 2013).

The essence of this approach is the harmony between the world of "human resources" (the potential to performance) which defines the organization's possibilities and the world of "human work" (the real performance) which is based on performance requirements (Plamínek and Fišer, 2005). The staff Management by Competencies must be lined up with the objectives and goals of the company and aims to provide the company or its managers with a logic methodology, which focuses on people, their development and, consequently, it focuses on corporate results; moreover, it has also targets in boosting immediate results and in granting sustainable long-term development (Aravena-Reyes et. al, 2005)

On the other side, there is also many disadvantages, this approach has to deal with:

- Biggest problem in the use of competency models lies in the lack of homogeneity in its definition and also in its amplitude (Markus et al., 2005)

- difficulties are often associated with the process complexity required in order to identify the appropriate competencies and also those associated with the construction process of a suitable model to the organizational reality (Svetlik et al., 2007)

- There is a great difficulty that companies face in the alignment of competencies and strategies (Fleury and Fleury, 2004)

Because of these and many other barriers, the management by competencies model eventually loses its usefulness, going often to be more a hindrance in the organization, rather than a system of management support.

\section{Conclusion}

In the overview has been debated the appropriate set of research fields related to competence approach of project managers. This set consist of five general topics allowing us to create adequate theoretical background for the future research.

When discussing the difference between competency and competence, to compare the meanings we can say the definition of competency as knowledge, skills, mindsets, thought patterns, and the like used whether singularly or in various combinations, result in successful performance and on the other side the competence is a function of worthy performance, which is a function of the ratio of valuable accomplishments to costly behavior. (Woodruffe, 1993; McConnell, 2001; Teodorescu, 2006; Hroník et al., 2008; Khan and Ramachandran, 2010, Leung et al., 2016)

Classification: Where it's possible to find scientific approaches to the classification depending on the most cited authors. In our future research related to project management seems to be most appropriated to focus on classification into 3 groups of competencies according to Sparrow and Hiltrop (1994) - behavioral, managerial, and core. In case the research specific requirements will show this classification as inadequate, other classification will be considered.

Model of competencies: This model refers to a group of competencies required in a particular job (usually 7-9 competencies) depending upon the nature and complexity of work along with the culture and values of the organization in which the work takes place, which can be developing for specific jobs, job groups, organizations, occupations or industries (Bozkurt, 2011)

Project management competencies: Due to Brill et al. (2006) understanding, project management is a complex process targeting multiple outcomes and project management competency is just as complex, requiring the acquisition of a variety of competencies - knowledge and skill sets that often cross areas of expertise, including instructional technology, management, information technology, engineering, and manufacturing.

Management by Competencies: According to Lišková and Tomšík (2013) the competency management system can help to improve the leadership and management of organizations that is based on competencies (MBO). In relation to our research it is perceived as powerful instrument.

We are going to explore the perception of competence / competency understanding among Czech project managers. As well management by competencies (MBC) is perceived as very actual topic (Lišková and Tomšík, 2013) which should be precisely researched in Czech companies to identify the current state of application of this approach and to be able to suggest adequate improvements.

Next up the model of project managers competencies will be designed through qualitative interviews in focus groups and then quantitatively validated. We presume that this model of project manager competences will be useful for a lot of personnel activities in a company. Whether it could support recruitment decisions, evaluation of project managers or indicate the appropriate field of competence development.

\section{Literature:}

1. ALOTAIBI A. and O. MAFIMISEBI, Project Management Practice: Redefining Theoretical Challenges in the 21st Century. Journal of Economics and Sustainable Development, 2016, 7(1). ISSN 2222-1700.

2. ARAVENA-REYES, J., M. BREGA, M. MOLINA, N. LINO and W. JUNIOR, 2005. Implementing Staff Management by Competencies: the experience of Daimler Chrysler of Brazil. LACCEI International Latin American and Caribbean Conference for Engineering and Technology [online]. 3. Available from: http://www.laccei.org/LACCEI2005-Cartagen a/Papers/IT060_AguilarMolina.pdf

3. AUBRET, J., P. GILBERT and F. PIGEYRE, (2005), Management des Compétences, Réalisations, Concepts, Analyses (2nd ed.), Paris: Dunod.

4. BOZKURT, T., 2011. Management by Competencies [online]. 2011. B.m.: Istanbul. Available from: http://ejournal. narotama.ac.id/files/Management by Competencies.pdf 5. BREDILLET, C., S. TYWONIAK and R. DWIVEDULA, 2015. What is a good project manager? An Aristotelian perspective. International Journal of Project Management [online]. 33(2), 254-266. Available from: http://10.1016/j. ijproman.2014.04.001

6. BRADY, T. and A. DAVIES, 2004. Building Project Capabilities: From Exploratory to Exploitative Learning. Organization Studies [online]. B.m.: SAGE Publications, 1. 11., 25(9), 1601-1621. ISSN 0170-8406. Available from: http://10.1177/0170840604048002

7. BRILL, J., M. BISHOP and A. WALKER, 2006. The Competencies and Characteristics Required of an Effective Project Manager: A Web-Based Delphi Study. Educational Technology Research \& Development [online]. B.m.: Springer 
Science \& Business Media B. V., 4., 54(2), 115-140. ISSN 10421629. Available from: http://10.0.3.239/s11423-006-8251-y 8. BROPHY, M. and T. KIELY, 2002. Competencies: A new sector. Journal of European Industrial Training [online]. B.m.: Emerald, 26(2/3/4), 165-176. ISSN 0309-0590. Available from: http://10.1108/03090590210422049

9. CHENG, M., A. DAINTY and D. MOORE, 2005. What makes a good project manager? Human Resource Management Journal [online]. B.m.: Wiley-Blackwell, 3., 15(1), 25-37. ISSN 09545395. Available from: http://search.ebscohost.com/ login.aspx ?direct $=$ true \&db=bsu\&AN=15908285\&lang $=$ cs\&site $=$ ehost-live $\mathrm{s}$

10. FLEURY, M. and A. FLEURY, 2004. Alinhando estratégia e competências. Revista de Administração de Empresas [online]. B.m.: Fundação Getulio Vargas/ Escola de Administração de Empresas de São Paulo /RAE-publicações, 3., 44(1), 44-57 [vid. 2017-03-11]. ISSN 2178-938X. Available from: http://10.15 90/S0034-75902004000100012

11. GARCÍA-ARACIL, A. and R. VELDEN, 2008. Competencies for young European higher education graduates: labor market mismatches and their payoffs. Higher Education [online]. B.m.: Springer Science \& Business Media B. V., 2., 55(2), 219-239. ISSN 00181560. Available from: http://10.0.3.239/s10734-006-9050-4

12. GANGANI, N., G. MCLEAN and R. BRADEN, 2008. A Competency-Based Human Resource Development Strategy. Performance Improvement Quarterly [online]. B.m.: Blackwell Publishing Ltd, 22. 10., 19(1), 127-139 [vid. 2017-03-12]. ISSN 08985952. Available from: http://10.1111/j.1937-8327.20 06.tb00361.x

13. HEIJKE, H., CH. MENG and G. RAMAEKERS, 2003. An investigation into the role of human capital competences and their pay-off. International Journal of Manpower [online]. B.m.: Emerald, 24(7), 750-773. ISSN 0143-7720. Available from: http://10.1108/01437720310502113

14. HOGAN, R. and R. WARRENFELTZ, 2003. Educating the Modern Manager. Academy of Management Learning \& Education [online]. B.m.: Academy of Management, 3., 2(1), 74-84. ISSN 1537260X. Available from: http://10.0.21.89/AMLE.2003.9324043

15. HOGAN, R. a R. KAISER, 2005. What we know about leadership. Review of general psychology [online]. B.m.: Educational Publishing Foundation, 9(2), 169. ISSN 143381725X. Available from: http://dx.doi.org/10.1037/10892680.9.2.169

16. HRONÍK, F. J. Vedralová and L. Horváth, 2008. Kompetenční modely: projekt ESF Učit se praxí. 1. Vyd. Brno: Motiv Press, ISBN 978-80-904133-2-0.

17. JORGE, F., B. GALLELI and J. BITTENCOURT, 2014. Avaliação de Competências em uma Instituição Hospitalar: A Visão de Avaliados e Avaliadores. Future Studies Research Journal: Trends and Strategies [online]. 1. 6., 6(1), 3-31 [vid. 2017-03-11]. ISSN 21755825. Available from: http://10.7444/fsrj.v6i1.157

18. KERZNER, H., 2013. Project management: a systems approach to planning, scheduling, and controlling. B.m.: John Wiley \& Sons. ISBN 111841585X.

19. KHAN, K. and S. RAMACHANDRAN, 2012. Conceptual framework for performance assessment: Competency, competence and performance in the context of assessments in healthcare - Deciphering the terminology. Medical Teacher [online]. B.m.: Taylor \& Francis Ltd, 11., 34(11), 920-928. ISSN 0142159X. Available from: http://10.0.12.37/0142 159X.2012.722707

20. KUIJPERS, M. (2000), "Career development competencies", Proceedings of the 2nd Conference of HRD Research \& Practice across Europe, University of Twente, Enschede, pp. 309-14. 21. LADO, A. and M. WILSON, 1994. Human resource systems and sustained competitive advantage: a competency-based perspective. Academy of Management Review [online]. B.m.: Academy of Management, 1. 10., 19(4), 699-727 [vid. 2017-0304]. ISSN 0363-7425. Available from: http://10.5465/A MR.1994.9412190216

22. LEUNG, K., L. TREVENA and D. WATERS, 2016. Development of a competency framework for evidence-based practice in nursing. Nurse Education Today [online]. 4., 39, 189-
196 [vid. 2017-03-04]. ISSN 02606917. Available from: http://10.1016/j.nedt.2016.01.026

23. LIŠKOVÁ, S. and P. TOMŠÍK, 2013. Competency-based approach to human resources management. Agricultural Economics-Czech [online]. 59(11), 496-504. Available from: http://agriculturejournals.cz/publicFiles/107005.pdf

24. LOUFRANI-FEDIDA, S. and S. MISSONIER, 2015. The project manager cannot be a hero anymore! Understanding critical competencies in project-based organizations from a multilevel approach. International Journal of Project Management [online]. 8., 33(6), 1220-1235 [vid. 2017-03-11]. ISSN 02637863. Available from: https://10.1016/j.ijprom an.2015.02.010

25. MARKUS, L., H. COOPER-THOMAS and K. ALLPRESS, 2005. Confounded by Competencies? An Evaluation of the Evolution and Use of Competency Models. New Zealand Journal of Psychology [online]. B.m.: New Zealand Psychological Society, 7., 34(2), 117-126. ISSN 0112109X. Available from: http://search.ebscohost.com/login.aspx?dire

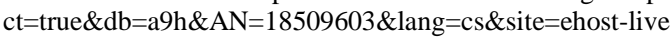
26. MCCONNELL, E., 2001. Competence vs. competency. Nursing Management [online]. Chicago: Springhouse Corporation, 5., 32(5), 14. ISSN 07446314. Available from: https://search.p roquest.com/docview/231440144?accountid=17115

27. NORDHAUG, Odd. Human capital in organizations: competence, training, and learning. New York: Oxford University Press, 1993. ISBN 978-8200218074.

28. PLAMÍNEK, J. and R. FIŠER, 2005. Rízení podle kompetencí. 1. vyd. Praha: Grada, 2005, 180 s. B.m.: ISBN 80247-1074-9.

29. RAINES, D., 2010. Nursing practice competency of accelerated bachelor of science in nursing program students. Journal of Professional Nursing [online]. 26(3), 162-167. Available from: http://10.1016/j.profnurs.2009.12.004

30. ROWE, CH., 1995. Clarifying the use of competence and competency models in recruitment, assessment and staff development. Industrial and Commercial Training [online]. B.m.: Emerald, 1. 12., 27(11), 12-17. ISSN 0019-7858. Available from: http://10.1108/00197859510100257

31. SÖDERLUND, J. and F. TELL, 2011. Strategy and capabilities in the P-form corporation: Linking strategic direction with organizational capabilities. In: Project-Based Organizing and Strategic Management. B.m.: Emerald Group Publishing Limited, s. 235-262. ISBN 0742-3322. Available from: http://dx.doi.org/10.1108/S0742-3322(2011)0000028013 32. SPARROW, P. and J. HILTROP, 1994. European human resource management in transition. New York: Prentice Hall. ISBN 01-320-2095-5.

33. SVETLIK, I., E. STAVROU-COSTEA, M. VAKOLA, K. SODERQUIST and G. PRASTACOS, 2007. Competency management in support of organisational change. International Journal of Manpower [online]. B.m.: Emerald Group Publishing Limited, 28(3/4), 260-275. ISSN 0143-7720. Available from: http://dx.doi.org/10.1108/01437720710755245

34. TEODORESCU, T., 2006. Competence versus competency: What is the difference? Performance Improvement [online]. B.m.: John Wiley \& Sons, Inc., 11., 45(10), 27-30. ISSN 10908811. Available from: http://10.0.3.234/pfi.027

35. WU, W. and Y. LEE, 2007. Developing global managers' competencies using the fuzzy DEMATEL method. Expert Systems with Applications [online]. 2., 32(2), 499-507 [vid. 2017-03-12]. ISSN 09574174. Available from: http://10.101 6/j.eswa.2005.12.005

Primary Paper Section: A

Secondary Paper Section: AE, AH 